\title{
DAMPAK SARAF TERJEPIT TERHADAP IBU HAMIL TRIMESTER III DI KLINIK PERA SIMALINGKAR B MEDAN
}

\author{
Hilda Yani Karo Karo
}

Universitas Audi Indonesia

Hildayanie354@gmail.com

\begin{abstract}
Pinched nerve is a disease that occurs due to nerve damage due to pressure, either direct or indirect pressure. Mothers who have a pinched nerve should sleep on their back on a flat, hard bed. Pregnant women in trimester III are prone to experiencing pinched nerves due to body changes in the mother such as body changes in the third trimester, namely, drastic weight gain caused by the growing fetus, back pain and pelvis, when you get closer to the time of delivery, the hormones- the body's hormones will change. The research approach used in this research is qualitative with the case study method. This qualitative approach was chosen in order to obtain broader and more indepth information on matters that are the subject of discussion for which answers should be found in this study. This research will be conducted at the Pera Maternity Clinic by selecting 4 cases of pregnant women who experience pinched nerves. The method of collecting data is the interview method because this method will get valid and direct information from the source.In the end, this research will produce a concept description about the extent of the impact of pinched nerves on third trimester pregnant women and the outputs that are targeted are publication in the journal Amenorrhoea, textbooks and prociding. The level of maturity condition or the level of readiness of a study on the impact of pinched nerves on third-to-sixth trimester pregnant women is associated with applied research.
\end{abstract}

Keywords: Pinched Nerves, Pregnant Women, Third Trimester, Pregnancy, Inferior Vena Cava

\section{PENDAHULUAN}

Tekanan berlebih pada saraf oleh jaringan sekitarnya biasa dikenal dengan sebutan saraf kejepit. Kondisi ini bisa menyebabkan rasa sakit, kebas, kesemutan, dan kelemahan dalam pergerakan (Alodokter, 2018). Angka Kematian Ibu (AKI) merupakan salah satu tolak ukur untuk menilai derajat kesehatan perempuan di suatu negara. Hasil Survei Demografi Kesehatan Indonesia (SDKI) tahun 2012 menunjukan Angka Kematian Ibu (AKI) di Indonesia mencapai 359 per 100.000 kelahiran hidup, sementara itu pemerintah mentargetkan dalam Millennium Development Goals (MDG's) pada tahun 2015 menjadi 108 per 100.000 kelahiran hidup. Menurut profil kesehatan tahun 2013 tercatat Angka Kematian Ibu (AKI) yang sampai saat ini tercatat terdapat 40 kasus. Jaringan sekitar yang bisa menekan saraf bisa berupa jaringan otot, tendon, tulang, 
atau tulang rawan. Karena saraf menjalar sepanjang tubuh, maka saraf kejepit juga bisa terjadi di berbagai lokasi dalam tubuh.

\section{Berdasarkan}

Community

Practicioner (2010), ibu hamil mengalami banyak sekali permasalahan selama kehamilannya yaitu pada ketidaknyamanan dan tentunya akan berdampak pada status kesehatan ibu hamil selama kehamilannya. Ketidaknyamanan yang dialami ibu diantaranya adalah masalah peregangangan ligamen pada daerah pubis yang menyebabkan nyeri pinggang, nyeri punggung, bahkan mengalami saraf terjepit, edema pada ibu hamil dengan peningkatan tekanan darah, kandidiasis vagina juga merupakan hal yang umum terjadi pada ibu selama kehamilan (Community Practicioner, 2010).

Kasus saraf terjepit juga umum terjadi pada pinggang bagian bawah. Penyebabnya bisa berbeda-beda, tergantung lokasi nyeri. Untuk di bagian pinggang, kemungkinan terjadi karena bantalan tulang yang keluar dan menonjol, sehingga menekan saraf di bagian tulang belakang dan terjepit. (Rizki, 2019).

Berdasarkan kajian yang dilakukan oleh Bullock et. Al (2011) menemukan bahwa sekitar 88,2\% wanita hamil yang mengalami nyeri punggung. Pada usia kehamilan 14 22 minggu, sekitar $62 \%$ wanita hamil yang melaporkan kejadian nyeri punggung bawah.

Menurut beberapa penelitian dilakukan ada hubungan yang dapat saling mempengaruhi antara Saraf Terjepit atau Herniated Nucleus Pulposus (HNP) dan juga kehamilan, seseorang yang mengalami saraf terjepit kemudian hamil bisa mengalami perburukan kondisi HNP nya atau seseorang yang tidak HNP namun karena kehamilannya akhirnya menjadi HNP.

Saraf kejepit adalah suatu kondisi di mana saraf tertekan oleh bagian sekitarnya. Ketika Anda mengalami kondisi saraf terjepit, tubuh Anda akan mengirimkan sinyal berupa rasa nyeri. Tentu sebaiknya Anda tidak remehkan tanda-tanda saraf kejepit, sebab kerusakan saraf bisa jadi besar.

Ada beberapa dampak yang dapat terjadi ketika saraf terjepit dibiarkan, seperti jaringan lunak atau pelindung di sekitar saraf dapat pecah. Hal tersebut dapat membentuk cairan, yang dapat menyebabkan pembengkakan, tekanan ekstra, dan jaringan parut. Jika saraf kejepit terjadi pada waktu yang singkat, tentu tidak ada kerusakan permanen pada saraf. Namun, jika tekanan terjadi terus menerus tentu saja saraf bisa rusak 
secara permanen.

Berdasarkan latar belakang diatas maka perlu dilakukan penelitian tentang Dampak Saraf Terjepit pada Ibu Hamil.

Tujuan penelitian ini adalah 1) mengetahui dampak yang terjadi pada proses persalinan pada ibu yang menderita saraf terjepit, 2) upaya yang dilakukan untuk mengurangi rasa sakit pada proses persalinan (treatmen yang dilakukan oleh dokter berbeda dengan keadaan ibu yang normal, 3) pembedaan perlakuan proses persalinan pada ibu yang menderita saraf terjepit dan yang tidak mengalami saraf terjepit.

\section{METODE}

Pendekatan penelitian yang digunakan dalam penelitian ini adalah kualitatif. Pendekatan kualitatif ini dipilih agar dapat memperoleh keterangan yang lebih luas dan mendalam mengenai hal-hal yng menjadi pokok pembahasan yang harus diketemukan jawabannya dalam penelitian ini. Penelitian dilakukan di Klinik Pera Jl. Bunga Rampe No. 77 Simalingkar B Medan Provinsi Sumatera Utara, waktu penelitian akan dilakukan pada tahun 2020. Populasi dalam penelitian ini Ibu Hamil Trimester III yang mengalami Saraf Terjepit di bulan Mei- Juli di klinik
Pera tahun 2019 yaitu sebanyak 4 kasus. Metode pengumpulan data dilakukan dengan pengisian kuisioner, studi literature, studi pustaka, dan wawancara yang berhubungan dengan variabel penelitian. Analisis yang digunakan dalam metode penelitian kulitatatif ini menggunakan analisis isi yang dapat digunakan dengan metode deduksi, induksi atau gabungan dari keduanya yang dikenal dengan analisis reflektif. Metode analisis data dalam penelitian ini menggunakan reduksi data dan penyajian data serta penarikan kesimpulan.

\section{HASIL DAN PEMBAHASAN}

Hasil

Hasil penelitian yang telah dilakukan oleh peneliti, untuk menjelaskan tentang dampak saraf terjepit terhadap Ibu Hamil Trimester III di Klinik Pera.

Peneliti akan memaparkan hasil penelitian ini dalam tiga bagian yaitu : 1) Deskripsi Lokasi Penelitian; 2) Informasi umum tentang karakteristik informasi sesuai dengan latar belakang dan konteks penelitian; dan 3) Deskripsi hasil penelitian berupa pengelompokan tema yang muncul dari transkip, catatan lapangan dan observasi yang didapatkan 
selama proses wawancara mendalam.

\subsection{Deskripsi Lokasi Penelitian}

Penelitian dilakukan di Klinik

Pera Kelurahan Simalingkar B, Kecamatan Medan Tuntungan, Kotamadya. Menurut pandangan Ibu Hamil, keadaan yang dialami Ibu selama hamil sangat mencemaskan dan membuat ibu merasa tidak nyaman, perubahan - perubahan yang di alami Ibu Hamil membuat ibu hamil merasa bingung dan khawatir dengan dirinya sendiri, apa lagi memasuki kehamilan Trimester III, dengan bertambahnya usia kehamilan Ibu, bertambah juga proporsi Tubuh Ibu, berkurangnya aktifitas Ibu di akibatkan karena terjadi peningkatan Berat Badan Ibu, maka Ibu Hamil rentan mengalami saraf terjepit. Penyebab terjadinya syaraf terjepit karena adanya kesalahan posisi pada waktu tidur atau salah posisi tubuh saat mengangkat beban yang berat.. Ibu hamil yang mengalami saraf terjepit dapat membahayakan keselamatan ibu dan janinnya jika persalinan secara spontan, karena ibu akan mengalami susah meneran. Kenyaman ibu juga terganggu, seperti posisi pada saat ibu tidur. Tujuan dari Kehamilan adalah sebagai sarana untuk meneruskan keturunan (fungsi reproduksi).

\subsection{Profile Informan}

Penelitian ini adalah penelitian deskripsi yang tidak hanya melakukan pengamatan dilapangan, namun penelitian ini juga menggunakan teknik wawancara kepada informan yang bersangkutan untuk mendapatkan informasi lebih detail. Informan disini dipilih sebanyak 4 orang Ibu Hamil. yakni 4 Orang Ibu Hamil Trimester III, Ibu Hamil A, Ibu Hamil B, Ibu Hamil C, dan Ibu Hamil D. Biodata informan disini menggunakan nama samaran atau menggunakan inisial huruf guna melindungi data asli keluarga yang menjadi target penelitian. Informan dipilih oleh peneliti guna memperoleh data yang lebih valid dan menampis kerancuan informasi dalam penelitian.

\subsection{Karakteristik Informan}

\subsubsection{Karakteristik Informan 1}

Kode informan : A

(Ny A) Perempuan berusia 38 tahun, Usia Kehamilan 30 Minggu beragama Kristen Protestan, status pernikahan sah menurut agama dan adat, pendidikan terakhir SMA, pekerjaan IRT. Suami informan pendidikan terakhir SMA, penghasilan gak tentu tiap harinya, usia istri saat pernikahan 26 tahun dan usia suami 27 tahun, usia pernikahan saat ini \pm 12 tahun. Ibu Hamil Mengatakan apabila tidur telentang, ibu merasa nyeri pinggang karena menyebabkan tekanan uterus terhadap vena cava inferior yang menimbulkan rasa sesak pada ibu hamil dan juga menyebabkan sirkulasi 
peredaran darah janin terhambat. Ibu hamil pada Trimester III rentan mengalami saraf terjepit dikarenakan perubahan tubuh pada ibu seperti perubahan tubuh di trimester III yaitu, kenaikan berat badan drastis diakibatkan oleh janin yang tumbuh semakin besar, sakit punggung dan panggul. Ternyata hasil menyatakan bahwa Ibu Hamil mengalami syaraf terjepit.

\subsubsection{Karakteristik Informan II}

Kode informan : B

(Ny B) Perempuan berusia 34 tahun, Usia Kehamilan 31 Minggu, beragama Katolik, status pernikahan sah menurut agama dan adat, pendidikan terakhir S1, pekerjaan PNS. Suami informan pendidikan terakhir D3, penghasilan \pm 2.800.000/bulan, usia istri saat pernikahan 28 tahun dan usia suami 30 tahun, usia pernikahan saat ini \pm 6 tahun. Suami membawa Ibu Hamil ke Klinik Pera guna pengecekan terhadap kejanggalan pada daerah nyeri punggung menjalar ke pinggang. Bidan menyatakan bahwa Ibu mengalami syaraf terjepit dibagian pinggang. Dokter menyatakan bahwa hal tersebut mungkin saja terjadi karna faktor bertambahnya Berat Badan Ibu dan Kehamilan Ibu yang semakin Membesar karena janin dalam kandungan ibu tumbuh semakin membesar.

\subsubsection{Karakteristik Informan III}

Kode informan : C

(Ny C) Perempuan berusia 36 tahun, Usia Kehamilan 32 Minggu, beragama Kristen Protestan, status pernikahan syah, pendidikan terakhir SMA, pekerjaan PNS. Suami infoman pendidikan terakhir SMA, penghasilan tidak tetap/bulan, usia istri saat pernikahan 30 tahun dan usia suami 31 tahun, usia pernikahan \pm 6 tahun. Ibu hamil mengatakan sering tidak nyaman pada Kehamilannya, apa lagi memasuki Trimester III dan selalu merasa nyeri pada daerah punggung menjalar ke pinggang. Syaraf terjepit merupakan penyakit yang terjadi karena kerusakan syaraf akibat tekanan, baik tekanan secara langsung maupun tidak secara langsung. Syaraf terjepit adalah penyakit yang sering dianggap remeh dan dipandang dengan sebelah mata, ternyata itu kesalahan yang besar sekali, karena saraf terjepit sangat berbahaya. Dimana syaraf terjepit bisa mengakibatkan penurunan sistem syaraf dalam menghantarkan sinyal dari otak ataupun sebaliknya. Penyebab terjadinya syaraf terjepit karena adanya kesalahan posisi pada waktu tidur atau salah posisi tubuh saat mengangkat beban yang berat. Ibu hamil yang mengalami saraf terjepit dapat membahayakan keselamatan ibu dan janinnya jika 
persalinan secara spontan, karena ibu akan mengalami susah meneran.

\subsubsection{Karakteristik Informan IV}

Kode informan : D

(Ny D) Perempuan berusia 27 tahun, beragama Islam, status pernikahan sah menurut agama dan adat, pendidikan terakhir SMA, pekerjaan Wiraswasta. Suami informan berumur 29 tahun, pendidikan terakhir SMA, penghasilan \pm 2.000.000/bulan, usia istri saat pernikahan 22 tahun dan usia suami 24 tahun, usia pernikahan saat ini \pm 5 tahun. Ibu mengatakan sering mengalami Nyeri Punggung sampai menjalar ke pinggang, apalagi tidur telentang. Dan ibu sering mengalami nyeri hebat setelah memasuki kehamilan Trimester III. Dan Ibu tidak tahu dan bingung dengan keadaan yang dirasakan ibu. Ibu pernah Konsul ke Praktik Bidan dan Bidan mengatakan gejala yang di alami Ibu adalah Saraf Terjepit.

\subsection{Gambaran Hasil Penelitian tentang Pengaruh Psikis Ibu Hamil yang Mengalami Saraf Terjepit}

Berikut ini merupakan keseluruhan tema yang terbentuk dari data yang terkumpul melalui wawancara, observasi dan tinjauan literatur. Beberapa tema yang teridentifikasi yaitu respon psikologis ibu hamil yang mengalami saraf terjepit. Ibu yang mengalami saraf terjepit harus tidur posisi telentang di tempat tidur yang datar dan keras. Sedangkan secara teori dikatakan bahwa ibu hamil tidak di anjurkan berbaring terlentang dalam jangka waktu yang lama karena menyebabkan tekanan uterus terhadap vena cava inferior yang menimbulkan rasa sesak pada ibu hamil dan juga menyebabkan sirkulasi peredaran darah janin terhambat. Ibu hamil pada Trimester III rentan mengalami saraf terjepit dikarenakan perubahan tubuh pada ibu seperti perubahan tubuh di trimester III yaitu, kenaikan berat badan drastis diakibatkan oleh janin yang tumbuh semakin besar, sakit punggung dan panggul, ketika Anda semakin dekat dengan waktu persalinan, maka hormon-hormon tubuh akan berubah. Perubahan hormon ini menyebabkan sendi antara tulang-tulang panggul mengendur, kondisi ini terjadi mengakibatkan ibu hamil merasakan nyeri dan justru hal ini yang menjadi penyebab sakit punggung pada ibu hamil dan mengalami saraf terjepit. nilai dan kepercayaan masyarakat Karo mengenai saraf terjepit.

\subsection{Respon Psikologis Perempuan yang Mengalami Saraf Terjepit \\ Berdasarkan hasil penelitian yang dilakukan dengan cara wawancara mendalam, didapatkan beberapa bentuk respon psikologis pada Ibu Hamil yang mengalami saraf terjepit yaitu :}




\subsubsection{Cemas}

Tujuan Kehamilan adalah untuk memiliki Bayi dan mempunyai keturunan, sehingga keseluruhan informan mengatakan sangat cemas karena perubahan - perubahan yang di alami ibu selama masa kehamilannya. Untuk pernyataan yang mengungkapkan kecemasannya disampaikan sebagai berikut :

"....semakin bertambah usia

kehamilan aku" rasa cemas itu

semakin bertambah dan tinggi,

memasuki usia kehamilan 7

bulan rasa nyeri di punggung

sampai pinggang semakin sakit

aku rasa (A)

“.....kalau kehamilan aku yang pertama aku gak pernah ngerasain nyeri punggung sampai ke pinngang, ini kehamilan kedua aku selalu merasakan nyeri sakit di punggung dan pinggang aku dek...selalu aku tanya sama suami, pasti jawab suami itu hal biasa kalau ibu hamil namanya perutnya besar, bukan bawak badan sendiri lagi udah yang di dalam perut dibawak bawak, ...hmmh, rasa cemas itu terus ada dek..(B)

“.....Cemas kalinya kurasa, apalagi kalau udah sakit kali aku rasa pinggang aku, sampek gak bisa berdiri aku, mau duduk pun gak nyaman, apalagi berjalan..." (C)

“...Aku merasakan saraf terjepit memasuki kehamilan 7 Bulan ke 8 bulan, awal nya punggung dan pinggang aku sakit, aku merasa cemas dan aku langsung ke praktik bidan, di bilang bidan, ibu sepertinya mengalami saraf terjepit, cemas kali aku..” (D) “...sangat sakit kali kali aku, cemas kali aku dibuat gejala saraf terjepit ini, apalagi kalau suami malah tidak peduli..” (C) "... sedih dan cemas kali aku kalau udah kumat saraf terjepit aku, kalo suami aku dibilangnya jangan manja kali lah mak katanya.." (B)

Perasaan cemas terkait dengan nyeri saraf terjepit ditunjukkan dengan ekspresi sedih dan takut pada informan 1 dan IV bahkan sampai menangis, tampak mengusap air mata dengan ujung bajunya, dan mata berkaca-kaca pada informan II, III dan V.

Masalah psikologis yang muncul pada ibu hamil yang mengalami saraf terjepit adalah perasaan kehilangan, diantaranya kehilangan semangat, takut, khawatir dan tidak nyaman dengan kehamilannya untuk 
mempertahankan bayinya, sehingga ketika ibu hamil melihat beberapa Ibu hamil merasa senang dan tidak pernah merasakan sakit atau ketidaknyamanan dengan kehamilannya, bahkan bergerak aktif seperti tidak hamil, maka timbul perasaan cemburu.

Tapi sebagai seorang perempuan, ibu hamil harus tetap semangat dan harus menjalankan therapy supaya Ibu sembuh dari saraf terjepitnya. peran sebagai ibu harus memenuhi salah satu tugas atau perannya yaitu hamil dan melahirkan.

\subsubsection{Khawatir}

Ibu hamil yang mengalami saraf terjepit mengalami khawatir. Rasa khawatir itu pasti akan muncul pada saat ibu merasakan sakit nyeri punggung menjalar ke pinggang yang hebat sampai ibu meringis karena menahan rasa sakitnya. Untuk menghilangkan rasa sakit saraf terjepit, ibu hamil membutuhkan therapi dan juga dukungan penyemangat dari suami dan keluarganya.

“...memasuki kehamilan 7 bulan aku sering merasa khawatir, karena menahan rasa sakit punggung dan pinggang saya..."(A)

“...Suami sering kali sepele dengan rasa sakit saraf terjepit yang aku alami, kalau kumat saraf terjepit aku, rasa khawatir aku tinggi sekali dek, bahkan air mata saya keluar, tapi suami aku diam aja, biasa itu kalau ibu hamil sakit punggung dan pinggang katanya..” (B)

“...Aku gak tau lagi mau gimana kalau udah sakit punggung aku sampai ke pinggang, mau gimana pun posisi dan mau ngapa ngapain pun gak bisa, semua serba salah, mau bergerak aja sakit kali, kalau udah kumat sakitnya aku khawatir kali, apa lagi aku pengen kali anak aku lahir sehat dan tidak terjadi apa -apa” (C) "Pokoknya dek, kalau udah sakit punggung sampai pinggang aku, rasa khawatir aku pun semakin tinggi, aku khawatir bayi aku terjadi apa $\operatorname{apa....."~(D)~}$

“....aku Khawatir beratlah dek, apalagi ada kata keluarga dari pihak suami, kehamilan kamu itu tidak normal, karena kamu terus merasa sakit sampai kamu menangis gara - gara sakit kamu, awas ada kelainan pada bayi kamu. Sehingga saya tidak ingin lagi bertemu dengan pihak keluarga suami aku.” (B)

Rasa Khawatir yang sering dirasakan oleh Ibu hamil pada trimester III yang mengalami saraf terjepit lebih 
sering didapatkan dari keluarga pihak suami, yakni dari mertua dan saudarasaudara perempuan suami. Ini terlihat dari informan B yang sangat tidak di pedulikan oleh suaminya dan di takut takuti oleh keluarga pihak suaminya “...tapi suami aku diam aja, biasa itu kalau ibu hamil sakit punggung dan pinggang katanya.." kehamilan kamu itu tidak normal, karena kamu terus merasa sakit sampai kamu menangis gara gara sakit kamu, awas ada kelainan pada bayi kamu sehingga timbul rasa Khawatir yang tinggi dan rasa sedih yang mendalam pada dirinya, hal ini jelas terlihat saat informan mengatakan tidak ingin bertemu lagi dengan pihak keluarga suaminya.

\subsubsection{Tidak Nyaman}

Ibu hamil yang mengalami saraf terjepit merasa tidak nyaman pada masa kehamilannya.

Syaraf terjepit merupakan penyakit yang terjadi karena kerusakan syaraf akibat tekanan, baik tekanan secara langsung maupun tidak secara langsung. Syaraf terjepit adalah penyakit yang sering dianggap remeh dan dipandang dengan sebelah mata, ternyata itu kesalahan yang besar sekali, karena saraf terjepit sangat berbahaya. Dimana syaraf terjepit bisa mengakibatkan penurunan sistem syaraf dalam menghantarkan sinyal dari otak ataupun sebaliknya. Penyebab terjadinya syaraf terjepit karena adanya kesalahan posisi pada waktu tidur atau salah posisi tubuh saat mengangkat beban yang berat.. Ibu hamil yang mengalami saraf terjepit dapat membahayakan keselamatan ibu dan janinnya jika persalinan secara spontan, karena ibu akan mengalami susah meneran. Kenyaman ibu juga terganggu, seperti posisi pada saat ibu tidur. Ibu yang mengalami saraf terjepit harus tidur posisi telentang di tempat tidur yang datar dan keras. Sedangkan secara teori dikatakan bahwa ibu hamil tidak di anjurkan berbaring terlentang dalam jangka waktu yang lama karena menyebabkan tekanan uterus terhadap vena cava inferior yang menimbulkan rasa sesak pada ibu hamil dan juga menyebabkan sirkulasi peredaran darah janin terhambat. Ibu hamil pada Trimester III rentan mengalami saraf terjepit dikarenakan perubahan tubuh pada ibu seperti perubahan tubuh di trimester III yaitu, kenaikan berat badan drastis diakibatkan oleh janin yang tumbuh semakin besar, sakit punggung dan panggul, ketika Anda semakin dekat dengan waktu persalinan, maka hormonhormon tubuh akan berubah. Perubahan hormon ini menyebabkan sendi antara tulang-tulang panggul mengendur, kondisi ini terjadi mengakibatkan ibu hamil merasakan nyeri dan justru hal ini yang menjadi penyebab sakit punggung 
pada ibu hamil dan mengalami saraf terjepit

“ tidak nyaman kali menjalankan masa kehamilan kalau sudah kumat sakit nyeri punggung sampai ke pinggang, yang kata bidan dan dokter itu adalah saraf terjepit..(A)

“....kemaren aku sempat konsultasi sama dokter karena Ketidaknyaman aku karena sakit yang aku rasakan pada punggung dan pinggang aku, apalagi pada kehamilan aku mikirkan semua cakap orang ...." (B)

“....kemaren itu, pernah rasa sakit itu gak datang lagi, tiba tiba memasuki kehamilan 8 bulan rasa sakit itu datang lagi, aku merasa tidak nyaman kali dek." (C)

“...Pokoknya tidak nyaman kali laah dek, kalau hamil mengalami saraf terjepit, sampai nangis aku menahan sakitnya.. "(D)

“....aku berpikir kadang berpikir ingin mengakhiri kehamilan aku sangkin sakitnya yang aku rasakan, apalagi suami kurang perhatian sama aku dan bayi dalam kandungan aku...." (B)
Saraf Terjepit memberikan dampak yang besar pada kesejahteraan fisik dan psikologis seseorang, sehingga kadang-kadang dapat mengakibatkan seseorang sampai pada suatu titik keputusasaan dan dapat mengakibatkan sesuatu yang fatal sampai ingin mengakhiri kehamilannya.

\subsection{Memberi Dukungan dari} Keluarga

Ibu Hamil A, B, C, dan D memerlukan keluarga yang bersifat demokratis dalam menuruti dan mengutamakan kebutuhan Ibu hamil yang mengalami saraf terjepit. Pihak Keluarga memberi dukungan terhadap Ibu Hamil A, B, C, dan D yang seringkali memiliki keinginan untuk disembuhkan dari saraf terjepit. Ibu hami yang didiagnosa baik dari segi medis maupun non medis bahwa mengalami syaraf terjepit. Pihak Keluarga mengupayakan berbagai pengobatan dan hasil yang didapatkan hanya berlaku sesaat. Ibu hamil yang menjalankan therapi seringkali mendapatkan perubahan fisik dari hasil terapi yang ia jalani dan memang benar bahwasanya setelah ibu hamil diterapi mendapatkan hasil yang menuai harapan untuk sembuh, namun lagi-lagi hasil yang didapatkan tidak berkembang dengan baik. keluarga 
disamping itu juga tak lupa untuk selalu memberi support ketika Ibu hamil sedang melakukan pengobatan dan membuat Ibu hamil tidak jenuh karena keadaan.

Pihak Keluarga juga selalu mengajarkan hal yang menyenangkan kepada ibu hamil agar senantiasa ibu tidak jenuh dan mengeluh terhadap keadaan yang di alami Ibu selama masa kehamilannya yang dihadapi. Justru suami dan pihak keluarga memberikan pelayanan yang baik untuk perkembangan pertumbuhan janin dalam kandungan Ibu dan juga kesehatan Ibu dimulai dari dukungan keluarga. Dukungan keluarga yang di berikan untuk Ibu adalah selalu memotivasi untuk semangat menjalani hidup dan mnenerima kekurangan sebagai kelebihan. Selain itu, keluarga memberi kenyamanan terhadap Ibu yang membuat Ibu merasa nyaman dan senantiasa tidak murung dan merasa sendiri menjalankan masa kehamilannya.

\section{Pembahasan}

Menjelaskan hasil-hasil penelitian, pembahasan interpretasi penelitian yang dilakukan dengan cara membandingkan hasil temuan penelitian dengan literatur yang ada.

\subsection{Interpretasi Hasil Penelitian}

Hasil penelitian ini sesuai dengan konsep yang dikemukakan oleh
Murray dan McKinney (2006) bahwa dampak psikologis pada Ibu Hamil yang mengalami saraf terjepit adalah Ibu hamil merasa khawatir, cemas, tidak nyaman dengan kehamilannya sehingga menimbulkan stres dan cemas dalam berbagai aspek dalam menghadapi masa kehamilannya dalam kehidupan seharihari.(Murray, 2007)

Hal yang sama dengan penelitian ini adalah hasil penelitian yang dilakukan oleh Lee (2001) dalam Anggreni, 2009 terhadap Ibu Hamil yang mengalami Saraf terjepit di Thailand yang memperoleh hasil terjadinya peningkatan kecemasan dan ketegangan pada perempuan yang mengalami saraf terjepit. Kecemasan dan ketegangan ini mengganggu dalam berhubungan dengan orang lain karena adanya sikap cemas yang tinggi yang berlebihan ketika berbicara dengan orang lain dan mudah terpicunya emosi jika ada pernyataan orang lain yang dianggap menyinggung kehamilannya.

Hasil penelitian yang telah dilakukan juga sesuai dengan hasil penelitian Ferrystoner, 2013 bahwa ibu hamil yang mengalami saraf terjepit mempunyai pasangan yang tidak memberikan semangat dan mendukung kehamilannya sering kali mengalami perasaan tertekan terutama pihak wanita yang pada akhirnya dapat jatuh pada keadaan depresi, cemas dan lelah yang 
berkepanjangan. Perasaan yang dialami para wanita tersebut timbul sebagai akibat dari hasil pemeriksaan, pengobatan dan penanganan yang terus menerus tidak membuahkan hasil. Hal inilah yang mengakibatkan wanita merasa kehilangan kepercayaan diri serta perasaan tidak enak terhadap diri sendiri, suami dan keluarga ataupun lingkungan dimana wanita itu berada.

Hasil ini juga sejalan dengan penelitian Abbey, 1994 dalam Bobak, 2004 yang mengemukakan bahwa wanita banyak yang mengalami stres terhadap pemeriksaan dan pengobatan, menempatkan kepentingan yang lebih besar dalam hal mempunyai anak dan menginginkan anak yang lebih banyak.(Abbey, A., Andrews, F. M., \& Halman, 1994)

Ada persamaan dengan teori yang disampaikan oleh Shapiro (2008) yang menyatakan bahwa dampak emosional pada Ibu hamil diwujudkan dengan depresi dan cemas. Syaraf terjepit merupakan penyakit yang terjadi karena kerusakan syaraf akibat tekanan, baik tekanan secara langsung maupun tidak secara langsung. Syaraf terjepit adalah penyakit yang sering dianggap remeh dan dipandang dengan sebelah mata, ternyata itu kesalahan yang besar sekali, karena saraf terjepit sangat berbahaya. Dimana syaraf terjepit bisa mengakibatkan penurunan sistem syaraf dalam menghantarkan sinyal dari otak ataupun sebaliknya. Penyebab terjadinya syaraf terjepit karena adanya kesalahan posisi pada waktu tidur atau salah posisi tubuh saat mengangkat beban yang berat.. Ibu hamil yang mengalami saraf terjepit dapat membahayakan keselamatan ibu dan janinnya jika persalinan secara spontan, karena ibu akan mengalami susah meneran. Kenyaman ibu juga terganggu, seperti posisi pada saat ibu tidur.

Ibu yang mengalami saraf terjepit harus tidur posisi telentang di tempat tidur yang datar dan keras. Sedangkan secara teori dikatakan bahwa ibu hamil tidak di anjurkan berbaring terlentang dalam jangka waktu yang lama karena menyebabkan tekanan uterus terhadap vena cava inferior yang menimbulkan rasa sesak pada ibu hamil dan juga menyebabkan sirkulasi peredaran darah janin terhambat. Ibu hamil pada Trimester III rentan mengalami saraf terjepit dikarenakan perubahan tubuh pada ibu seperti perubahan tubuh di trimester III yaitu, kenaikan berat badan drastis diakibatkan oleh janin yang tumbuh semakin besar, sakit punggung dan panggul, ketika Anda semakin dekat dengan waktu persalinan, maka hormon-hormon tubuh akan berubah. Perubahan hormon ini menyebabkan 
sendi antara tulang-tulang panggul mengendur, kondisi ini terjadi mengakibatkan ibu hamil merasakan nyeri dan justru hal ini yang menjadi penyebab sakit punggung pada ibu hamil dan mengalami saraf terjepit.

Menurut (Bobak, 2005), dari beberapa perubahan yang terjadi pada ibu hamil, yang berdampak pada ketidaknyamanan ibu hamil yang disebabkan oleh nyeri pinggang, punggung dan bahkan saraf terjepit atau HNP yaitu pada sistem Muskuloskeletal, dimana Pertambahan berat badan saat hamil dapat menyebabkan seorang wanita memiliki kondisi syaraf kejepit atau HNP. Perubahan tubuh secara bertahap dan peningkatan berat badan ibu hamil menyebabkan postur dan cara berjalan ibu hamil berubah secara mencolok. Pergerakan menjadi lebih sulit, gaya berjalan ibu hamil yang bergoyang. Struktur ligamentum dan otot tulang belakang bagian tengah dan bawah mendapat tekanan berat. Perubahan ini dan perubahan lain terkait menimbulkan rasa nyeri dan menimbulkan rasa tidak nyaman pada muskuloskeletal.

Pada wanita hamil trimester III akan mengalami perubahan Fisiologis dan psikologis dan merupakan waktu untuk mempersiapkan kelahiran. Pada kehamilan trimester III terjadi ketidaknyamanan seperti, Edema devenden dan Varises, kedua hal ini disebabkan oleh gangguan sirkulasi vena dan meningkatnya tekanan vena pada ekstremitas bagian bawah.. Nyeri Ligemen, ligament teres uteri melekat di sisi-sisi tepat dibawah uterus. Nyeri punggung bawah tepatnya pada lumbosakral yang diakibatkan terjadinya pergeseran pusat gravitasi dan postur tubuh ibu hamil, yang semakin berat seiring semakin membesarnya uterus. Pengaruh sikap tubuh lordosis membungkuk berlebihan, jalan tanpa istirahat, mengangkat beban berat terutama dalam kondisi lelah.

\section{KESIMPULAN DAN SARAN}

\section{Kesimpulan}

Berdasarkan hasil penelitian dan uraian pembahasan dapat disimpulkan tentang bagaimana pengaruh psikis ibu hamil yang mengalami saraf terjepit. Respon psikologis yang muncul pada ibu hamil yang mengalami infertilitas adalah Cemas, Khawatir dan merasa ketidaknyamanan pada kehamilannya.

Adaptif yang dilakukan oleh Ibu hamil yang mengalami saraf terjepit adalah peningkatan spiritual, berpikir positif, dukungan dari suami dan keluarga, tidak putus asa melakukan pengobatan dan dan tetap semangat dalam menjalankan kehamilannya.

Respon Ibu hamil yang 
mengalami saraf terjepit sangat dipengaruhi oleh faktor internal dan eksternal. Faktor internal terdiri dari persepsi Ibu tentang arti masa kehamilan, perubahan - perubahan yang terjadi pada masa kehamilam, nilai seorang janin dalam kandungan sedangkan faktor eksternal dipengaruhi oleh nilai dan kepercayaan.

Dari semua pemaparan di atas, dapat disimpulkan bahwa setiap ibu hamil yang mengalami saraf terjepit dalam merespon dan mempunyai perasaan perubahan yang terjadi pada masa kehamilannya khususnya pada kehamilan Trimester III mempunyai peran yang berbeda-beda. Suami dan Keluarga yang memiliki tingkat kesadaran yang positif maka akan memiliki dampak yang baik bagi psikis Ibu hamil. Dengan dukungan motivasi, semangat yang diberikan kepada ibu selama masa kehamilannya membuat ibu semangat dalam menjalankan masa kehamilannya dan ibu termotivasi untuk menjalankan pengobatan dan therapi pengobatan saraf terjepit yang di alami Ibu hamil.

\section{Saran}

Berbagai saran yang diberikan peneliti terhadap pihak-pihak terkait dalam hal ini adalah :

\section{Bagi Ibu Hamil Yang Mengalami Saraf Terjepit}

Dalam menghadapi masalah saraf terjepit, diharapkan ibu harus berusaha meningkatkan kepercayaan diri dengan berbagai cara dan upaya diantaranya peningkatan spiritualitas, tetap melakukan pengobatan dan tetap semangat dalam menghadapi setiap perubahan - perubahan yang dialami Ibu selama masa kehamilannya.

\section{Bagi Instansi Kesehatan dan Praktek Pelayanan Kebidanan}

1. Bidan dalam menyusun asuhan kebidanan pada ibu hamil dengan saraf terjepit harus memahami nilai dan kepercayaan setempat, sehingga dalam memberikan asuhan dapat menyesuaikan dengan kepercayaan dan ciri khas yang ada dan mampu mendorong agar meningkatkan respon adaptif sehingga pelayanan yang diberikan bisa diterima dengan baik.

2. Bidan sebagai pelayan kesehatan hendaknya lebih menyediakan waktu untuk memberikan konseling atau sosialisasi/penyuluhan mengenai saraf terjepit dan pencegahannya sehingga Ibu hamil tidak merasa cemas, khawatir dengan kehamilannya.

\section{Bagi Pengembangan}

\section{Penelitian Selanjutnya}

1. Perlu dilakukan penelitian serupa dengan informan yang lebih bervariasi sehingga data yang dihasilkan lebih lengkap. 
2. Perlu dilakukan penelitian lebih lanjut dengan penggunaan metode penelitian lain, menggabungkan kualitatif dan kuantitatif sehingga hasilnya diharapkan dapat lebih mendukung penelitian yang telah dilakukan.

3. Perlu dilakukan penelitian lebih lanjut dengan karakteristik informan yang lebih heterogen, berasal dari berbagai strata sosial ekonomi, pendidikan dan pekerjaan.

\section{DAFTAR PUSTAKA}

Abbey, A., Andrews, F. M., \& Halman, L. J. (1994). Provision and receipt of social support and disregard: What is their impact on the marital life quality of infertile and fertile couples? Journal of Personality and Social Psychology, 68(3), 455469.

Alodokter. (2018). Sakit di Persendian Bisa Disebabkan Saraf Kejepit. https://www.alodokter.com/sakitdi-persendian-bisa-disebabkansyaraf-kejepit

Bobak, L. (2005). Keperawatan Maternitas, Edisi 4. EGC.

Community Practicioner. (2010). Pregnancy Part Serven: Minor Discomforts and Medical Complications. ProQuest Nursing \& Allied Health Source.

Murray, S. S. \& E. S. M. (2007). Foundations of MaternalNewborn Nursing 4th Edition. Saunders.

Rizki, V. L. P. (2019). Perawatan Saraf Terjepit saat Masa Kehamilan. https://www.motherandbaby.co.id/ article/2019/1/5/11578/PerawatanSaraf-Terjepit-saat-Masa-

Kehamilan 